\title{
Artificial selection for increased comb size and its effects on other sexual characters and viability in Gallus domesticus (the domestic chicken)
}

\author{
TORBJÖRN VON SCHANTZ*, MÅNS TUFVESSON $\dagger$, GÖRGEN GÖRANSSON, \\ MATS GRAHN, MARTIN WILHELMSON $\uparrow$ \& HÄKAN WITTZELL $\ddagger$ \\ Department of Animal Ecology, Ecology Building, University of Lund, S-223 62 Lund, †Department of Animal \\ Breeding and Genetics, Swedish University of Agricultural Sciences, Funbo-Lövsta, S-755 97 Uppsala and \\ $\ddagger$ Department of Theoretical Ecology, Ecology Building, University of Lund, S-223 62 Lund, Sweden
}

\begin{abstract}
The expression of secondary ornaments is often positively correlated with the bearer's condition. So far no study has reported on consequences of directional selection on male sexual ornaments in birds, i.e. it is unknown to what extent male sexual traits are genetically correlated and whether selection for secondary ornaments affects viability. In this study we estimate phenotypic and genotypic parameters of three male sexual traits, namely comb size, spur length and testes mass, by using two different lines of domestic chickens (Gallus domesticus). One of the two lines had been artificially selected for large comb size during nine generations whereas the other line was a randomly mated control line. As a result of the selection, male comb size was almost doubled. Data from the selection line indicate that comb size was negatively genetically correlated with testes mass and spur length. The cockerels from the selection line had accordingly lighter testes and shorter spurs than cockerels from the control line. A simple mate choice experiment with females and males from both lines indicated that preferred males had a larger joint expression of comb size and spur length than nonpreferred males. Data from three different selection lines, all with enlarged comb size, clearly reveal a negative effect of comb size on male viability.
\end{abstract}

Keywords: artificial selection, domestic chicken, genetic correlations, male ornaments, phenotypic correlations, viability.

\section{Introduction}

Much recent research has focused on the evolution of male sexual ornaments and the correlations between male condition-dependent ornamentation and female mate choice (Kirkpatrick \& Ryan, 1991). Theoretical analyses have emphasized the importance of phenotypic plasticity as a prerequisite for the condition-dependent expression of ornaments (Andersson, 1986; Grafen, 1990a,b). Assuming that, for example, age, infectious diseases and other extrinsic and intrinsic factors affect the individual's condition it follows that the degree to which an ornament is expressed will vary during the individual's life span. Accordingly, many studies have pointed out that sexual ornaments often are more

${ }^{*}$ Correspondence. variable, both for measures of repeatability and coefficients of variation, than other morphological characters (Alatalo et al., 1988; Zuk et al., 1990b; Wittzell, 1991a) and that the expression of these ornaments in some cases correlates with, for example, parasitic load (Hillgarth, 1990; Milinski \& Bakker, 1990; Zuk et al., 1990a; Møller, 1991a) and viability (Göransson et al., 1990; Møller, 1991b; Grahn, 1993).

The relative contributions of additive and nonadditive components to the phenotypical variation of male sexual ornaments is seldom measured in birds. Some studies have found only low heritabilities of male ornaments that affect female mate choice (Wittzell, 1991a; Johnson et al., 1993) whereas other studies have reported significant heritabilities of such ornaments (Møller, 1989b, 1991a; Hill, 1991). So far no study has reported on the consequences of 
directional selection on a male sexual ornament, e.g. it is unknown to what extent male sexual traits are genetically correlated and whether selection for an ornament affects viability.

The red jungle fowl (Gallus gallus) belong to the family Phasianidae within the order of Galliformes. Male ornaments that have been particularly focused on in studies of Phasianidae are the comb of the jungle fowl and the spurs of the pheasant (Phasianus colchicus). The size and colour of the males' comb were affected by the parasitic load in the red jungle fowl. Males with larger combs had not only fewer parasites but were also more preferred in the females' mate choice (Zuk et al., 1990a,b). In pheasants it has been demonstrated that male spur length correlates positively both with male viability (Göransson et al., 1990; Wittzell, 1991a; Grahn, 1993) and with female mate choice (von Schantz et al., 1989).

The red jungle fowl is considered to be the wild ancestor of domestic chicken (Gallus domesticus) (Kruijt, 1964). In the present study we estimate phenotypic and genotypic parameters of three male sexual traits, namely comb size, spur length and testes mass. Two lines of White Leghorn were used in this comparison. One of the two lines has been artificially selected for large comb size during nine generations (line $\mathrm{S}$ ) whereas the other line was a randomly mated control (line $\mathrm{C}$ ) with the same origin as the selection line. The relations between morphology, inbreeding and mortality are also analysed. In these latter comparisons we also used two additional selection lines of White Leghorn (lines $\mathrm{E}$ and $\mathrm{H}$ ), both of which have a larger comb size than the control line.

We also performed a mate choice experiment with a sample of males and females from lines $\mathrm{S}$ and $\mathrm{C}$ to see if comb size is a character that is of significance for female mate choice in the domestic chicken as is the case for the red jungle fowl (Zuk et al., 1990b). The domestic chickens in this study have been bred with artificial inseminations without any active female choice during at least 25 generations. It therefore seemed necessary to confirm that the male comb is an intersexually selected character also in the White Leghorns used in this study.

\section{Materials and methods}

\section{Lines of White Leghorn}

Together with a pharmaceutical company, the Swedish University of Agricultural Sciences is undertaking a project concerning genetical develop- ment of production of hyaluronic acid from cockerel combs. The breeding stock was obtained from White Leghorn lines in the Scandinavian selection and crossbreeding experiment with laying hens, as previously described by Liljedahl et al. (1979). At the start of the project in 1984, four lines were created excluding the control line which was housed externally during the first three generations. At the time of this study the selection had continued for nine generations. The generation interval was 42 weeks for the first seven generations and then changed to 52 weeks over the last two generations.

In the present study we used two of these lines to measure phenotypic and genetic parameters of morphological traits, one of the selected lines and the control line. The selected line (S) has been selected for comb size at 29 weeks of age and the control line (C) has been randomly mated over all nine generations. The relations between morphology, inbreeding and mortality were also analysed for the cockerels in lines $\mathrm{S}$ and $\mathrm{C}$. In addition to these two lines we also used data from two other selection lines in the breeding project ( $\mathrm{E}$ and $\mathrm{H}$ ) to reveal effects of comb size on viability. Line $\mathrm{E}$ has been selected for comb size at 23 weeks of age and line $\mathrm{H}$ has been selected for concentration of hyaluronic acid in the combs. Data from lines $\mathrm{E}$ and $\mathrm{H}$ are used for analyses of phenotypic effects on mortality.

For each generation all chicks were hatched and raised simultaneously under identical conditions. The chicks were sexed and raised in a cage system under ordinary recommended conditions. At 14 weeks of age the chicks were moved to a separate house where the cockerels were kept in pairs in cages for laying hens, modified in height. The hens were placed in single hen cages for layers. The animals were fed ad libitum with a mixture that was similar to commercial layer food. Mortality for both cockerels and hens was measured after 14 weeks of age in each of generations 7-9. In the ninth generation, line $\mathrm{S}$ consisted of 375 male offspring (14 weeks old) from 20 sires and 104 dams and line C consisted of 83 male offspring (14 weeks old) from 59 sires and 61 dams.

Male comb size and body mass were measured at 16, 23 and 29 weeks of age. Height and length of the comb were measured in millimetres using a ruler and the product used as an approximation of comb size. Comb size has been measured in all generations.

The length of the cockerels' spurs in the ninth generation in lines $\mathrm{S}$ and $\mathrm{C}$ was measured at 29 and 52 weeks of age. The distance between the tip of the spur and the distal edge of the tarsus was measured 
to the nearest $0.1 \mathrm{~mm}$ with a caliper. This measure minus the diameter of the tarsus just above the spur was used as a measure of spur length. At 29 weeks of age only the spur on the left tarsus was measured. At 52 weeks of age the spurs on both tarsi were measured and the mean value was used in the analysis.

The inbreeding coefficients were taken from the diagonal of the relationship matrix, where each diagonal element represents Wright's (1922) coefficient of inbreeding for each animal, respectively. The computing strategy used is described by Quaas (1976).

At the termination of the spur length measurement at 52 weeks of age, 40 cockerels and 20 hens from each of lines $\mathrm{S}$ and $\mathrm{C}$ were randomly selected for a subsequent mate choice experiment (see below). No further morphological measurements were taken from these animals and all mortality that occurred after this date was ignored in the present analysis. The remaining cockerels, 240 from line S and 37 from line $\mathrm{C}$, were slaughtered at the age of 55 weeks and the total mass of their two testes measured $(\mathrm{g})$.

At the age of 29 weeks, when the first spur length measurement was taken, 350 cockerels from 20 sires and 104 dams and 79 cockerels from 59 sires and 61 dams were alive in lines $S$ and $C$, respectively. As only one or two cockerels from each sire were raised in line $\mathrm{C}$ all genetic analyses were made on the line $\mathrm{S}$ cockerels. Genetic parameters were estimated by the method of least squares analysis of data with unequal subclass numbers, using the LSMLMw of Harvey (1985). Heritabilities and genetic correlations were estimated from the variance and covariance components between sires.

The following statistical model was used for estimating the genetic parameters (Harvey, 1985):

$Y_{i j k}=\mu+s_{i}+d_{i j}+e_{i j k}$,

where $Y_{i j k}$ is the observation of the $k$ th individual of the $j$ th dam within the $i$ th sire, $\mu$ is the general mean, $s_{i}$ is the effect of the $i$ th sire, $d_{i j}$ is the effect of the $j$ th dam within the $i$ th sire, and $e_{i j k}$ is the residual random term.

In the selection line (S) a negative variance was estimated between sires for comb size at 29 weeks of age. Therefore no genetic parameters involving this trait were estimated.

The statistics of observed (phenotypic) values, inbreeding coefficients and mortality are according to sYSTAT (Steinberg \& Colla, 1991; Wilkinson, 1992). Probability tests are two-tailed. Logistic regression analyses were performed in the LOGIT- module of SYSTAT (Steinberg \& Colla, 1991) using the likelihood ratio test (Hosmer \& Lemeshow, 1989) for probability tests. Multivariate general linear models were performed in the MGLHmodule of SYSTAT using SAS type III sums-of-squares (Wilkinson, 1992). Interactions between predictor variables were not significant.

\section{Trials of female mate choice}

Twenty females and 40 males from each of the selection line $S$ and the control line $C$, i.e. 120 birds in all, were used in the mate choice trials. All birds were 52 weeks old and none of them had been in visual contact with the other sex prior to the experiment. The experimental set-up was designed to resemble that of Zuk et al. (1990b) in their experimental study of mate choice in the red jungle fowl. Females were put in a $50 \mathrm{~m}^{2}$ outdoor enclosure and males were placed in pairs, not mixing males from the two different lines, in small compartments $\left(2 \mathrm{~m}^{2}\right)$ next to the main enclosure. The birds were allowed to acclimatize in their new environment for 4 weeks. A test arena was made from wooden boards assembled in a T-shape, forming two compartments (Zuk et al., 1990b). For the trials one male from each line was picked at random and tethered in the inner corner of the individual compartment. The males were separated by a wooden board and the tethering string allowed natural movements but no visual contact with the other male. One female from either the selection line or the control line was placed in a pen facing the two males. Hence, the female had full view of the two males and the males could see the hen but not each other.

The behaviour of males and females was observed through a window from a room next to the test arena. A device was arranged so that the pen housing the female could be opened by pulling a string from the observation room. After $15 \mathrm{~min}$ the female was released from the pen. The female was allowed a closer inspection of the cockerels for an additional 15 min. Hence, each mate choice trial lasted a total of $30 \mathrm{~min}$ during which the observer noted the numbers of crows and 'tidbittings' (when the male picks at the ground and makes small noises; Zuk et al., 1990b) performed by the males. The females' mating behaviour was scored in three classes; none, affiliating (the female did clearly associate with one of the males) and soliciting (the female crouched on the ground in front of the male; Zuk et al., 1990b). We did not observe any copulation during these trials. Each bird was only used once in the mate choice trials, three females of each of the two lines 
died before the onset of the trials. Hence, a total of 34 trials was performed.

\section{Results}

\section{Phenotypic parameters}

As a consequence of the selection, comb size was significantly larger for line $\mathrm{S}$ than for line $\mathrm{C}$ at all ages (Table 1). Selection on large comb size in nine generations resulted in an almost two-fold increase in comb size. The males of line $S$ were also heavier than those of line $\mathrm{C}$ at the ages of 16 and 23 weeks. However, at the age of 29 weeks the average body mass of both lines was almost identical (Table 1).

In contrast to comb size, the spurs were longer in the control line than in the selection line (Table 1).

Table 1 General statistics for the selection and control lines, of body mass and comb size (measured when the chickens were 16, 23 and 29 weeks old), spur length (measured at the ages of 29 and 52 weeks) and testes mass measured when the cockerels were dissected at an age of 55 weeks

\begin{tabular}{|c|c|c|c|}
\hline & Selection line S & Control line $\mathrm{C}$ & $t$ \\
\hline Body mass $_{16}(\mathrm{~g})$ & $\begin{array}{l}\bar{x}=1,618 \\
\mathrm{SD}=154 \\
\mathrm{CV}=9.5 \% \\
N=350\end{array}$ & $\begin{array}{l}\bar{x}=1,477 \\
\mathrm{SD}=138 \\
\mathrm{CV}=9.4 \% \\
N=79\end{array}$ & $\begin{array}{c}7.83 \\
P<0.001\end{array}$ \\
\hline 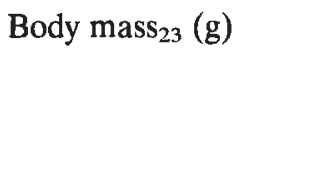 & $\begin{array}{l}\bar{x}=1,833 \\
\mathrm{SD}=189 \\
\mathrm{CV}=10.3 \% \\
N=350\end{array}$ & $\begin{array}{l}\bar{x}=1,757 \\
\mathrm{SD}=145 \\
\mathrm{CV}=8.3 \% \\
N=79\end{array}$ & $\begin{array}{l}3.37 \\
P=0.001\end{array}$ \\
\hline Body mass $_{29}(\mathrm{~g})$ & $\begin{array}{l}\bar{x}=1,901 \\
\mathrm{SD}=169 \\
\mathrm{CV}=8.9 \% \\
N=349\end{array}$ & $\begin{array}{l}\bar{x}=1,900 \\
\mathrm{SD}=138 \\
\mathrm{CV}=9.4 \% \\
N=79\end{array}$ & $\begin{array}{l}0.03 \\
\text { NS }\end{array}$ \\
\hline Comb size ${ }_{16}\left(\mathrm{~mm}^{2}\right)$ & $\begin{array}{l}\bar{x}=7,775 \\
\mathrm{SD}=2,188 \\
\mathrm{CV}=28.1 \% \\
N=350\end{array}$ & $\begin{array}{l}\bar{x}=3,910 \\
\mathrm{SD}=1,102 \\
\mathrm{CV}=28.2 \% \\
N=79\end{array}$ & $\begin{array}{c}15.3 \\
P<0.001\end{array}$ \\
\hline Comb size $23\left(\mathrm{~mm}^{2}\right)$ & $\begin{array}{l}\bar{x}=12,395 \\
\mathrm{SD}=1,872 \\
\mathrm{CV}=15.1 \% \\
N=350\end{array}$ & $\begin{array}{l}\bar{x}=6,677 \\
\mathrm{SD}=1,138 \\
\mathrm{CV}=17.0 \% \\
N=79\end{array}$ & $\begin{array}{c}26.1 \\
P<0.001\end{array}$ \\
\hline Comb size $_{29}\left(\mathrm{~mm}^{2}\right)$ & $\begin{array}{l}\tilde{x}=13,317 \\
\mathrm{SD}=2,118 \\
\mathrm{CV}=15.9 \% \\
N=349\end{array}$ & $\begin{array}{l}\bar{x}=7,150 \\
\mathrm{SD}=1,380 \\
\mathrm{CV}=19.3 \% \\
N=79\end{array}$ & $\begin{array}{c}24.7 \\
P<0.001\end{array}$ \\
\hline Spur length $_{29}(\mathrm{~mm})$ & $\begin{array}{l}\bar{x}=7.9 \\
\mathrm{SD}=2.7 \\
\mathrm{CV}=34.2 \% \\
N=350\end{array}$ & $\begin{array}{l}\bar{x}=9.7 \\
\mathrm{SD}=2.7 \\
\mathrm{CV}=27.9 \% \\
N=79\end{array}$ & $\begin{array}{c}5.49 \\
P<0.001\end{array}$ \\
\hline Spur length $_{52}(\mathrm{~mm})$ & $\begin{array}{l}\bar{x}=18.2 \\
\mathrm{SD}=4.4 \\
\mathrm{CV}=24.3 \% \\
N=304\end{array}$ & $\begin{array}{l}\bar{x}=21.6 \\
\mathrm{SD}=4.1 \\
\mathrm{CV}=19.2 \% \\
N=79\end{array}$ & $\begin{array}{c}\quad 6.28 \\
P<0.001\end{array}$ \\
\hline Testes mass ${ }_{55}(\mathrm{~g})$ & $\begin{array}{l}\bar{x}=11.0 \\
\mathrm{SD}=6.4 \\
\mathrm{CV}=58.1 \% \\
N=240\end{array}$ & $\begin{array}{l}\bar{x}=16.8 \\
\mathrm{SD}=5.4 \\
\mathrm{CV}=32.2 \% \\
N=37\end{array}$ & $\begin{array}{c}5.16 \\
P<0.001\end{array}$ \\
\hline
\end{tabular}


In addition, the cockerels in line $\mathrm{C}$ had heavier testes than those in line $\mathrm{S}$ (Table 1).

The phenotypic correlations between comb size and body mass showed a different pattern for the two lines of cockerels (Tables 2 and 3). Comb size of the control line males did not correlate phenotypically with body mass at any of the ages (Table 3 ). In contrast, among cockerels in line S, comb size and body mass were positively correlated at each of the three ages (Table 2). However, although comb size in the selection line correlated positively with body mass when the cockerels were 16 weeks old, the phenotypic correlations were negative between comb size at the age of 16 weeks $\left(\mathrm{CS}_{16}\right)$ and body mass measured at the ages of 23 and 29 weeks (Table 2).
Such a shift in the relation between comb size and body mass was not present in the data on comb size from weeks 23 and 29 (Table 2). The negative correlations between $\mathrm{CS}_{16}$ and subsequent body mass measures $\left(\mathrm{BM}_{23}\right.$ and $\left.\mathrm{BM}_{29}\right)$ are not the result of differential mortality as only individuals that were alive at week 29 are included in the analysis. Hence it is the same sample of individuals that are remeasured in this analysis. It therefore seems likely that those cockerels in the selection line that had developed a large comb at an early stage of their lives (at week 16) increased less in body mass later on. This notion is supported by a multiple regression analysis showing that the change in body mass between weeks 16 and 29 among cockerels in line S

Table 2 Phenotypic correlations between the various measurements taken at different ages of the cockerels from the selection line $\mathrm{S}$

\begin{tabular}{|c|c|c|c|c|c|c|c|c|c|}
\hline & $\mathrm{BM}_{16}$ & $\mathrm{BM}_{23}$ & $\mathrm{BM}_{29}$ & $\mathrm{CS}_{16}$ & $\mathrm{CS}_{23}$ & $\mathrm{CS}_{29}$ & $\mathrm{SL}_{29}$ & $\mathrm{SL}_{52}$ & $\mathrm{TM}_{55}$ \\
\hline $\mathrm{BM}_{23}$ & $0.54 * * *$ & - & & & & & & & \\
\hline $\mathrm{BM}_{29}$ & $0.53^{* * *}$ & $0.77^{* * *}$ & - & & & & & & \\
\hline $\mathrm{CS}_{16}$ & $0.37^{* * *}$ & $-0.17^{*}$ & $-0.21 * *$ & - & & & & & \\
\hline $\mathrm{CS}_{23}$ & $0.33^{* * *}$ & $0.18^{*}$ & 0.07 & $0.54 * * *$ & - & & & & \\
\hline $\mathrm{CS}_{29}$ & $0.33^{* * *}$ & $0.25^{* * *}$ & $0.20^{* *}$ & $0.46^{* * *}$ & $0.67^{* * *}$ & - & & & \\
\hline $\mathrm{SL}_{29}$ & 0.06 & $0.26^{* * *}$ & $0.30^{* * *}$ & -0.05 & -0.01 & 0.08 & - & & \\
\hline $\mathrm{SL}_{52}^{\dagger}$ & 0.04 & $0.26^{* * *}$ & $0.33^{* * *}$ & -0.11 & 0.03 & 0.04 & $0.78^{* * *}$ & - & \\
\hline $\mathrm{TM}_{55}^{\mathrm{t}}$ & 0.17 & $0.32^{* * *}$ & $0.32 * * *$ & -0.13 & 0.00 & 0.06 & $0.30^{* * *}$ & $0.29 * * *$ & - \\
\hline IC & -0.08 & 0.04 & 0.03 & -0.02 & 0.04 & 0.01 & -0.06 & -0.06 & -0.03 \\
\hline
\end{tabular}

BM: body mass; CS: comb size; SL: spur length; TM: testes mass; IC: inbreeding coefficient.

$N=350$ unless otherwise stated.

$\dagger N=304, \ddagger N=240$.

Bonferroni-adjusted probabilities: ${ }^{*} P<0.05,{ }^{* *} P<0.01,{ }^{* * *} P<0.001$.

Table 3 Phenotypic correlations between the various measurements taken at different ages of the cockerels from the control line $\mathrm{C}$

\begin{tabular}{|c|c|c|c|c|c|c|c|c|c|}
\hline & $\mathrm{BM}_{16}$ & $\mathrm{BM}_{23}$ & $\mathrm{BM}_{29}$ & $\mathrm{CS}_{16}$ & $\mathrm{CS}_{23}$ & $\mathrm{CS}_{29}$ & $\mathrm{SL}_{29}$ & $\mathrm{SL}_{52}$ & $\mathrm{TM}_{55}$ \\
\hline $\mathrm{BM}_{23}$ & $0.80^{* * *}$ & - & & & & & & & \\
\hline $\mathrm{BM}_{29}$ & $0.80^{* * *}$ & $0.89^{* * *}$ & - & & & & & & \\
\hline $\mathrm{CS}_{16}$ & 0.15 & -0.02 & 0.00 & - & & & & & \\
\hline $\mathrm{CS}_{23}$ & 0.08 & 0.07 & 0.06 & $0.63^{* * *}$ & - & & & & \\
\hline $\mathrm{CS}_{29}$ & 0.10 & 0.09 & 0.01 & $0.59^{* * *}$ & $0.76^{* * *}$ & - & & & \\
\hline $\mathrm{SL}_{29}$ & 0.10 & 0.02 & 0.11 & 0.22 & 0.09 & 0.15 & - & & \\
\hline $\mathrm{SL}_{52}$ & 0.20 & 0.16 & $0.24^{*}$ & 0.18 & 0.04 & 0.08 & $0.79 * * *$ & - & \\
\hline $\mathrm{TM}_{S S}^{\dagger}$ & 0.39 & 0.42 & 0.47 & 0.01 & -0.06 & -0.14 & 0.37 & $0.54^{*}$ & - \\
\hline IC & -0.22 & -0.14 & -0.20 & -0.12 & -0.10 & -0.03 & -0.11 & -0.08 & 0.05 \\
\hline
\end{tabular}

Labels as in Table 2.

$N=79$ unless otherwise stated.

$\dagger N=37$.

Bonferroni-adjusted probabilities: ${ }^{*} P<0.05,{ }^{* * *} P<0.001$. 
was negatively correlated with $\mathrm{CS}_{16}$ even when the effect of $\mathrm{BM}_{16}$ was partialled out (Table 4; partial $r=-0.52, N=349, P<0.001$ ).

There were no consistent phenotypic correlations between comb size and spur length or comb size and testes mass in either of the two lines (Tables 2 and 3).

Spur length $\left(\mathrm{SL}_{29}\right.$ and $\left.\mathrm{SL}_{52}\right)$ and body mass $\left(\mathrm{BM}_{23}\right.$ and $\mathrm{BM}_{29}$ ) were significant phenotypic predictors of testes mass in line S (Table 2). In the control line, $\mathrm{SL}_{52}$ was a significant phenotypic predictor of testes mass (Table 3).

The inbreeding coefficient was significantly larger in line $S(\bar{x}=0.107, S D=0.033)$ than in line $C$ $(\bar{x}=0.006, \mathrm{SD}=0.013, t=428, P<0.001)$. In no case did the inbreeding coefficient correlate with any phenotypical character (Tables 2 and 3).

Table 4 Multiple regression analysis, and partial correlation coefficients, on data from selection line $\mathrm{S}$ with the cockerels' change in body weight (g) between week 16 and week 29 as the dependent variable and comb size at week $16\left(\mathrm{~mm}^{2}\right)$ and body weight at week $16(\mathrm{~g})$ as predictors

\begin{tabular}{lcccc}
\hline & Coefficient & Partial $\boldsymbol{r}$ & $\boldsymbol{t}$ & $\boldsymbol{P}$ \\
\hline Constant & 919.0 & - & - & - \\
CS $_{16}$ & -0.037 & -0.52 & -11.34 & $<0.001$ \\
BM $_{16}$ & -0.217 & -0.24 & -4.71 & $<0.001$ \\
\hline
\end{tabular}

Multiple $r=0.62, N=349$.

\section{Genetic parameters}

Genetic correlations in line $\mathrm{S}$ between comb size, spur length and testes mass are given in Table 5. The estimated heritabilities were fairly high for all characters measured except for $\mathrm{CS}_{23}$ which was surprisingly low compared with previous results which have yielded estimates ranging between 0.3 and 0.4 in all generations (Tufvesson et al., 1993).

Although we found no phenotypic correlations between comb size and spur length at any age, these characters appeared to be negatively correlated genetically (Table 5). Comb size at all ages also seemed to be negatively genetically correlated with testes mass (Table 5). Note that the standard errors are substantial in these correlations. In contrast, the genetic correlations between spur length and testes mass were positive and had only small standard errors (Table 5).

\section{Mortality}

Thirteen per cent of the cockerels in line $S$ that were alive at week 29 had died by week 52 whereas none of the cockerels belonging to line $\mathrm{C}$ died during the same period. It seems that the cockerels of the selection line were less viable than those of the control line. The same pattern with an increased mortality among the cockerels of line $\mathrm{S}$ is also found in the two previous generations (Table 6). The data in Table 6 also indicate that the females of the selection line did not suffer from an overall increased mortality in comparison with the males and females of the control line.

Table 5 Heritabilities and genetic correlations of comb size, spur length and testes mass of the cockerels from the selection line $\mathrm{S}$

\begin{tabular}{lrrrrr}
\hline & \multicolumn{1}{c}{$\mathrm{CS}_{16}$} & \multicolumn{1}{c}{$\mathrm{CS}_{23}$} & $\mathrm{SL}_{29}$ & $\mathrm{SL}_{52}$ & $\mathrm{TM}_{55}$ \\
\hline $\mathrm{CS}_{16}$ & $0.35(0.20)$ & & & & \\
$\mathrm{CS}_{23}$ & $1.27(0.88)$ & $0.04(0.10)$ & & & \\
$\mathrm{SL}_{29}$ & $-0.43(0.29)$ & $-0.66(0.81)$ & $0.75(0.30)$ & & \\
$\mathrm{SL}_{52}^{ \pm}$ & $-0.36(0.32)$ & $-0.54(0.70)$ & $0.91(0.06)$ & $0.83(0.33)$ & \\
$\mathrm{TM}_{55}^{ \pm}$ & $-0.42(0.37)$ & $-0.70(0.60)$ & $0.94(0.15)$ & $0.88(0.17)$ & $0.46(0.29)$ \\
\hline
\end{tabular}

Labels as in Table 2.

The values in the diagonal denote the heritabilities of the characters. The values below the diagonal express the genetic correlation between two characters.

Standard error estimates are given within parentheses.

The analyses are based on variance- and covariance components between sires (number of sires was 20).

The total number of offspring $(N)$ is 350 unless otherwise stated. Computations could not be performed for $\mathrm{CS}_{29}$ as this variable yielded a negative variance (Harvey, 1985).

$\dagger N=304, \ddagger N=237$. 
Table 6 Mortality of both males and females in the last three generations of the selection line $\mathrm{S}$ and the control line $\mathrm{C}$

\begin{tabular}{|c|c|c|c|c|c|c|c|c|c|}
\hline \multirow[b]{2}{*}{ Generation } & \multirow[b]{2}{*}{$\chi^{2}$-test $\ddagger$} & \multicolumn{3}{|c|}{ Selection line $\mathrm{S}$} & \multicolumn{3}{|c|}{ Control line $\mathrm{C}$} & \multirow[b]{2}{*}{ MM } & \multirow[b]{2}{*}{ FF } \\
\hline & & Males & MF & Females & Males & MF & Females & & \\
\hline 7 th & $\begin{array}{l}\text { Number alive } \dagger \\
\text { Number dead } \ddagger \\
\text { Mortality }(\%)\end{array}$ & $\begin{array}{l}558 \\
63 \\
11.3\end{array}$ & $* *$ & $\begin{array}{c}607 \\
40 \\
6.6\end{array}$ & $\begin{array}{l}150 \\
2 \\
0.1\end{array}$ & NS & $\begin{array}{l}154 \\
3 \\
1.9\end{array}$ & $* * *$ & $*$ \\
\hline 8th & $\begin{array}{l}\text { Number alive } \dagger \\
\text { Number dead } \$ \\
\text { Mortality }(\%)\end{array}$ & $\begin{array}{l}530 \\
94 \\
17.7\end{array}$ & $* * *$ & $\begin{array}{c}488 \\
30 \\
6.1\end{array}$ & $\begin{array}{l}127 \\
3 \\
2.4\end{array}$ & NS & $\begin{array}{c}161 \\
9 \\
5.6\end{array}$ & $* * *$ & NS \\
\hline 9th & $\begin{array}{l}\text { Number alive } \dagger \\
\text { Number dead } \dagger \dagger \\
\text { Mortality (\%) }\end{array}$ & $\begin{array}{l}375 \\
66 \\
17.6\end{array}$ & $* * *$ & $\begin{array}{l}445 \\
8 \\
1.8\end{array}$ & $\begin{array}{l}83 \\
4 \\
4.8\end{array}$ & NS & $\begin{array}{l}112 \\
5 \\
4.5\end{array}$ & $* * *$ & NS \\
\hline
\end{tabular}

Mortality is calculated from week 14, i.e. when the chicks were moved from the rearing house to the stable, until the week when the birds were slaughtered.

$\dagger$ At week 14 ; fby week 47 ; §by week 60 ; ††by week 52 .

¥MF test difference between males and females within lines; MM difference between males between lines; FF difference between females between lines.

${ }^{*} P<0.05,{ }^{* *} P<0.01,{ }^{* * *} P<0.001$.

Table 7 Comparison of cockerels from the selection line $S$ in generation 9 that survived or died between weeks 29 and 52

\begin{tabular}{|c|c|c|c|}
\hline & Survivors $(N=304 \dagger)$ & Nonsurvivors $(N=46)$ & $t$ \\
\hline Body mass $_{16}(\mathrm{~g})$ & $\begin{array}{l}\bar{x}=1,621 \\
\mathrm{SD}=156 \\
\mathrm{CV}=9.9 \%\end{array}$ & $\begin{array}{l}\bar{x}=1,602 \\
\mathrm{SD}=140 \\
\mathrm{CV}=8.7 \%\end{array}$ & $\begin{array}{l}0.79 \\
\text { NS }\end{array}$ \\
\hline Body mass $_{23}(\mathrm{~g})$ & $\begin{array}{l}\bar{x}=1,837 \\
\mathrm{SD}=190 \\
\mathrm{CV}=10.3 \%\end{array}$ & $\begin{array}{l}\bar{x}=1,801 \\
\mathrm{SD}=179 \\
\mathrm{CV}=9.9 \%\end{array}$ & $\begin{array}{l}1.22 \\
\mathrm{NS}\end{array}$ \\
\hline 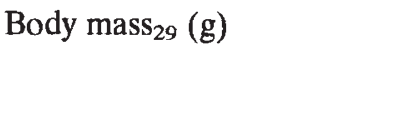 & $\begin{array}{l}\bar{x}=1,911 \dagger \\
\mathrm{SD}=165 \\
\mathrm{CV}=8.6 \%\end{array}$ & $\begin{array}{l}\bar{x}=1,825 \\
\mathrm{SD}=180 \\
\mathrm{CV}=9.9 \%\end{array}$ & $P=\begin{array}{l}3.28 \\
0.001\end{array}$ \\
\hline $\begin{array}{l}\text { Change in body mass (g) } \\
\text { between week } 16 \text { and } 29\end{array}$ & $\begin{array}{l}\bar{x}=291 \dagger \\
\mathrm{SD}=152 \\
\mathrm{CV}=52.2 \%\end{array}$ & $\begin{array}{l}\bar{x}=224 \\
S D=178 \\
C V=79.4 \%\end{array}$ & $P=0.007$ \\
\hline Comb size $_{16}\left(\mathrm{~mm}^{2}\right)$ & $\begin{array}{l}\bar{x}=7,741 \\
\mathrm{SD}=2,205 \\
\mathrm{CV}=28.5 \%\end{array}$ & $\begin{array}{l}\bar{x}=7,995 \\
\mathrm{SD}=2,082 \\
\mathrm{CV}=26.0 \%\end{array}$ & $\begin{array}{l}0.73 \\
\text { NS }\end{array}$ \\
\hline Comb size $23\left(\mathrm{~mm}^{2}\right)$ & $\begin{array}{l}\bar{x}=12,325 \\
\mathrm{SD}=1,891 \\
\mathrm{CV}=15.3 \%\end{array}$ & $\begin{array}{l}\bar{x}=12,852 \\
\mathrm{SD}=1,694 \\
\mathrm{CV}=13.2 \%\end{array}$ & $\begin{array}{l}1.78 \\
\text { NS }\end{array}$ \\
\hline Comb size $29\left(\mathrm{~mm}^{2}\right)$ & $\begin{array}{l}\bar{x}=13,332 \\
\mathrm{SD}=2,106 \\
\mathrm{CV}=15.8 \%\end{array}$ & $\begin{array}{l}\bar{x}=13,216 \\
\mathrm{SD}=2,216 \\
\mathrm{CV}=16.8 \%\end{array}$ & $\begin{array}{l}0.35 \\
\text { NS }\end{array}$ \\
\hline Spur length $_{29}(\mathrm{~mm})$ & $\begin{array}{l}\bar{x}=8.0 \\
\mathrm{SD}=2.7 \\
\mathrm{CV}=34.4 \%\end{array}$ & $\begin{array}{l}\hat{x}=7.1 \\
\mathrm{SD}=2.1 \\
\mathrm{CV}=30.2 \%\end{array}$ & $\begin{array}{r}2.18 \\
P=0.03\end{array}$ \\
\hline
\end{tabular}

$\dagger N=303$. 
Table 8 Mortality of cockerels in relation to $\mathrm{CS}_{16}, \mathrm{BM}_{16}$, inbreeding coefficient and generation in the three selection lines (lines S, H and $\mathrm{E}$ ) and the control line $\mathrm{C}$

\begin{tabular}{|c|c|c|c|c|c|}
\hline Line & Variable & Coefficient & d.f. & $-2 \log \mathrm{LR}$ & $P$ \\
\hline $\mathrm{S}(N=1,463)$ & $\begin{array}{l}\mathrm{CS}_{16} \\
\mathrm{BM}_{16} \\
\text { Inbreeding coefficient } \\
\text { Generation }\end{array}$ & $\begin{array}{l}0.0001233 \\
-0.0009671 \\
-2.71 \\
-\end{array}$ & $\begin{array}{l}1 \\
1 \\
1 \\
2\end{array}$ & $\begin{array}{r}11.14 \\
3.29 \\
0.72 \\
7.74\end{array}$ & $\begin{array}{c}<0.0001 \\
\text { NS } \\
\text { NS } \\
<0.05\end{array}$ \\
\hline $\mathrm{H}(N=1,537)$ & $\begin{array}{l}\mathrm{CS}_{16} \\
\mathrm{BM}_{16} \\
\text { Inbreeding coefficient } \\
\text { Generation }\end{array}$ & $\begin{array}{l}0.0002391 \\
-0.0007977 \\
1.01 \\
-\end{array}$ & $\begin{array}{l}1 \\
1 \\
1 \\
2\end{array}$ & $\begin{array}{r}9.24 \\
1.24 \\
0.07 \\
33.27\end{array}$ & $\begin{array}{c}<0.001 \\
\text { NS } \\
\text { NS } \\
<0.00001\end{array}$ \\
\hline $\mathrm{E}(N=1,521)$ & $\begin{array}{l}\mathrm{CS}_{16} \\
\mathrm{BM}_{16} \\
\text { Inbreeding coefficient } \\
\text { Generation }\end{array}$ & $\begin{array}{l}0.0001470 \\
-0.0018028 \\
-2.60 \\
-\end{array}$ & $\begin{array}{l}1 \\
1 \\
1 \\
2\end{array}$ & $\begin{array}{r}11.13 \\
10.47 \\
0.81 \\
8.33\end{array}$ & $\begin{array}{c}<0.0001 \\
<0.0001 \\
\text { NS } \\
<0.05\end{array}$ \\
\hline $\mathrm{C}(N=360)$ & $\begin{array}{l}\mathrm{CS}_{16} \\
\mathrm{BM}_{16} \\
\text { Inbreeding coefficient } \\
\text { Generation }\end{array}$ & $\begin{array}{l}-0.0000182 \\
-0.0011145 \\
-47.06 \\
-\end{array}$ & $\begin{array}{l}1 \\
1 \\
1 \\
2\end{array}$ & $\begin{array}{l}0.01 \\
0.19 \\
0.76 \\
2.73\end{array}$ & $\begin{array}{l}\text { NS } \\
\text { NS } \\
\text { NS } \\
\text { NS }\end{array}$ \\
\hline
\end{tabular}

Data are from generations 7-9.

Survivors are those cockerels that were alive by week 47 in the 7 th generation, by week 60 in the 8 th generation and by week 52 in the 9th generation.

Mortality is measured binarily (' 0 ': survivors, ' 1 ': nonsurvivors).

The analyses are based on logistic regression with generation as main effect and $\mathrm{CS}_{16}\left(\mathrm{~mm}^{2}\right), \mathrm{BM}_{16}(\mathrm{~g})$ and inbreeding coefficient as covariates (Steinberg \& Colla, 1991).

Probability tests are according to the maximum likelihood ratio test (Hosmer \& Lemeshow, 1989).

A comparison within line $S$ between cockerels that died or survived between weeks 29 and 52 revealed that the survivors: (i) had increased more in weight between weeks 16 and 29 and were heavier at week 29; and (ii) had longer spurs at week 29 (Table 7). The inbreeding coefficient did not differ between the survivors $(\bar{x}=0.106, N=304)$ and the nonsurvivors $(\bar{x}=0.106, N=46)$ in this comparison; nor was there any difference in comb size between the survivors and the nonsurvivors in this sample from line S (Table 7). Some mortality had already taken place before week 29 and data from these cockerels are not included in Table 7.

As mentioned above, $\mathrm{CS}_{16}$ was negatively correlated with the increase in body mass between weeks 16 and 29 in line $S$ when controlling for the effect of $\mathrm{BM}_{16}$ (Table 4). Logistic regression analyses including all cockerels in the three selection lines $\mathrm{S}, \mathrm{E}$ and $\mathrm{H}$ from generations 7-9 that were alive by week 16 show that those individuals that died later on had larger comb size at week 16 than those that survived until they were slaughtered (at the age of 47-60 weeks; Table 8 and Fig. 1). Hence, cockerels that had developed a large comb at an early age suffered from increased mortality later on. $\mathrm{CS}_{16}$ did not differ between survivors and nonsurvivors in line $\mathrm{C}$ (Table 8 and Fig. 1). It should be noted that line $\mathrm{H}$ has been selected for concentration of hyaluronic acid in the comb and not for increased comb size, as has been the case for lines $S$ and $E$. Yet the comb size at 16 weeks of age in line $\mathrm{H}$ has increased to some extent because of selection in comparison with the control line (Fig. 1).

Logistic regression analyses revealed no difference in inbreeding coefficients between survivors and nonsurvivors in generations 7-9 in any of the lines (S, E, H and C) (Table 8). 


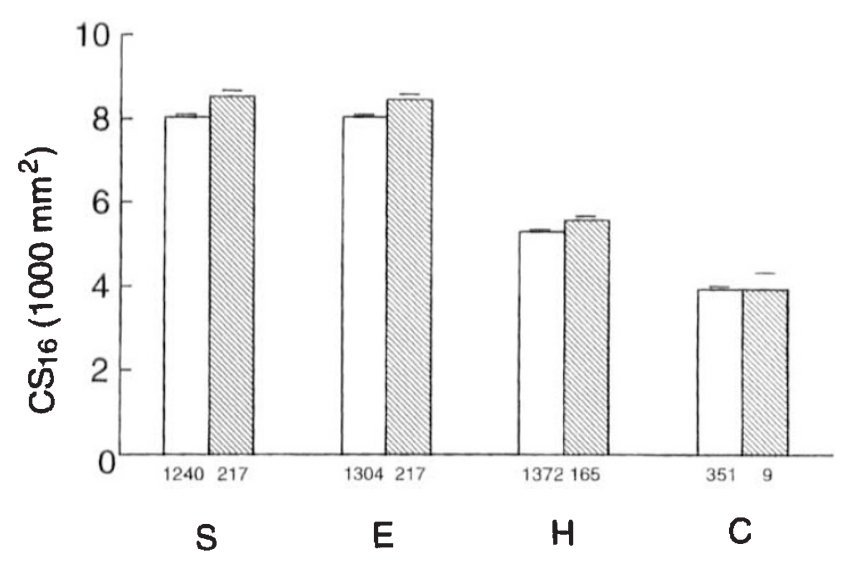

Fig. 1 Least square means of comb size at 16 weeks of age $\left(\mathrm{CS}_{16}\right)$ for survivors (open bars) and nonsurvivors (hatched bars) in a two-way analysis of covariance with mortality and generation as main effects and $\mathrm{BM}_{16}$ as covariate (Wilkinson, 1992) for generations 7-9 in the three selection lines ( $\mathrm{S}, \mathrm{E}$ and $\mathrm{H}$ ) and the control line (C). The standard errors of the least square means are given at the top of each bar and the total number of individuals in each group is given under the bars. Survivors are those cockerels that were alive by week 47 in the 7 th generation, by week 60 in the 8 th generation and by week 52 in the 9 th generation.

\section{Female choice}

Within the mate choice trials, males of line $\mathrm{S}$ had significantly larger combs $\left(\mathrm{CS}_{29}, \bar{x}\right.$ difference $=6,376$ $\left.\mathrm{mm}^{2}, F_{1,66}=102, P<0.001\right)$ and shorter spurs $\left(\mathrm{SL}_{52}\right.$, $\bar{x}$ difference $=2.4 \mathrm{~mm}, F_{1,66}=6.61, P=0.012$ ) than the males from line C. $\mathrm{CS}_{29}$ was negatively correlated with $\mathrm{SL}_{52}(r=-0.248, N=68, P=0.041)$. The two male lines did not differ in body mass, crowing, courtship behaviour, body and comb condition at the trials (data not shown). Of the 11 females belonging to line $\mathrm{S}$ that selected a male, eight preferred line $\mathrm{S}$ males and three favoured males of line $C$. The 14 line $\mathrm{C}$ females that made a choice selected a line $\mathrm{S}$ male in 10 cases and a line $\mathrm{C}$ male in four cases. Hence, in 18 cases a line $\mathrm{S}$ male was preferred by the females compared with seven for line $\mathrm{C}$ males; this difference deviated significantly from a random preference $(P=0.04$, two-tailed binomial test). Preferred males had larger comb size than nonpreferred males $\left(\tilde{x}\right.$ difference $=3,013 \mathrm{~mm}^{2}, \quad F_{1,48}=7.524$, $P=0.009)$. Preferred and nonpreferred males did not differ in spur length $(\bar{x}$ difference $=-0.67 \mathrm{~mm}$, $F_{1,48}=0.402, P=0.53$ ). However, in a geometric mean regression analysis (Sokal \& Rohlf, 1995) between $\mathrm{CS}_{29}$ and $\mathrm{SL}_{52}$, preferred males had significantly higher residual values than nonpreferred males $\left(F_{1,48}=6.026, P=0.018\right)$. Hence, preferred males had a larger joint expression of comb size and spur length than nonpreferred males.

\section{Discussion}

Comb size, a sexual ornament that is important for female choice in Gallus (Zuk et al., 1990b; this study), was experimentally increased by artificial selection (Table 1). Artificial selection on comb size resulted in negative responses in other sexual traits, i.e. spur length and testes mass (Table 1) and in a reduction of male viability. The results indicate that there may be genetic trade-offs between different sexual traits (Table 5) and that there are genetic as well as environmental mechanisms that relate the variation in comb size to male viability.

Given an additive variation in genetic quality it is obvious that mate choice can increase offspring fitness even in systems without parental care (Hamilton \& Zuk, 1982; Andersson, 1986; Grafen, 1990a,b; but see Kirkpatrick \& Ryan, 1991). As individuals can rarely examine their partner's genotype directly they have to rely on phenotypical cues, e.g. vigour or external characters that correlate with vigour. Some of these condition-related characteristics may be momentarily expressed signals that are particularly exposed in the males' sexual display, such as erected wattles or vigorous behavioural displays at lekking sites. These traits are likely to reveal the males' instant condition which directly can affect the fecundity or survival of females, e.g. through the males' ability to fertilize the females' ova or through the risk of transmission of infectious diseases from acutely afflicted males (Kirkpatrick \& Ryan, 1991). In birds such 'display traits' rarely correlate with male mating success in a quantitative sense (Bradbury \& Davies, 1987) but may often be necessary stimuli for females to accept copulation (Andersson, 1991). Other male secondary sexual traits are more or less permanently expressed without any direct behavioural inducement. In birds, many of these ornaments have been found to correlate with female choice (e.g. different tail characteristics (Andersson, 1982; Møller, 1988; Höglund et al., 1990, 1992) and plumage traits (Norris, 1990)) and with male viability as well (e.g. male spur length (von Schantz et al., 1989) and comb size (Zuk et al., 1990a), length of tail feathers (Møller, 1991b) and plumage colour (Hill, 1991)). To date a few of these studies have reported on significant heritabilities of viabilitybased male secondary ornaments (Hill, 1991; Møller, 1991a; Norris, 1993). The data presented in the present study demonstrate a case of additive genetic variation in a male ornament. 


\section{Correlations of male ornaments}

Genetic trade-offs, or antagonistic pleiotropy, between different traits is often suggested to be one reason for the maintenance of genetic variation for characters that affect fitness (e.g. Falconer, 1981; Rose, 1982; Hoffman \& Parsons, 1989; Partridge \& Fowler, 1993).

In the selection line comb size appeared to be negatively genetically correlated with spur length (Table 5). However, the estimated genetic correlations have large standard errors (Table 5) and it should be noted that estimates of genetic correlations are commonly associated with large sampling errors (Falconer, 1981). The fact that cockerels that were selected for large comb size in line $S$ had shorter spurs than cockerels from the unselected control line (Table 1) verifies a genetic trade-off between comb size and spur length.

\section{Male ornaments and 'handicaps'}

A common ingredient in recent models of sexual selection is that the ornament should confer a 'handicap' to its bearer to ensure the conditiondependent expression of the ornament (Andersson, 1986). The rationale is that it is only individuals of high phenotypic condition that can afford the cost of expressing an exaggerated ornament. The reason why female choice can not induce an evolution of 'noncostly' sexual ornaments is that females choosing among potential mates are selected to avoid being deceived by cheating males signalling a higher quality than they actually have (Zahavi, 1975, 1977; Kodric-Brown \& Brown, 1984). In the case of condition-dependent ornamentation, the males are expected to carry an ornament of a size that is optimized in relation to their condition (Andersson, 1986;

Grafen, 1990a,b) and hence males of better quality would possess larger sized ornaments. Such a positive correlation between viability and ornamentation has now been found in a number of studies (Møller, 1989a; Göransson et al., 1990; Hill, 1991; Grahn, 1993).

Data presented here indicate that there is a cost associated with the expression of comb size. There was a weak negative genetic correlation between comb size and testes mass among cockerels from line $S$ (Table 5). The average testes mass of the cockerels from line $\mathrm{S}$ was accordingly lower than that of the cockerels from the control line (Table 1). Testes size in birds is directly correlated both with sperm production and the males' ability to insem- inate the females successfully (Burrows \& Titus, 1939; Martin \& Dziuk, 1977; Brillard \& de Reviers, 1985 ) and with male territoriality (Tsuij et al., 1992).

Costs in terms of reduced survival for an exaggerated male trait have been found in a few nonexperimental studies (Endler, 1980; Tuttle \& Ryan, 1981 ) and in one case it has been experimentally demonstrated that increased ornamental size reduced the survival of the bearer (Møller, 1989a).

Several analyses (Tables 6-8, Fig. 1) indicate that there is a viability cost associated with the expression of the comb. Undoubtedly inbreeding has an effect on mortality in general (Falconer, 1981) but our data (Table 8) indicate that inbreeding has only a minor influence on the viability cost associated with the comb size at 16 weeks of age found in the three selection lines. Comb size at this age was significantly larger for individuals that died later on in comparison with those cockerels that were recorded as survivors in each of the three selection lines (Table 8 and Fig. 1). The fact that these correlations are significant in all of the three selection lines makes it unlikely that the negative effect of $\mathrm{CS}_{16}$ on viability is the result of genetic drift.

It appears therefore that the cockerels in the three selection lines express a comb size that confers a net cost in terms of overall condition. In contrast, cockerels from the control line are more likely to express their comb size in accordance with their phenotypical condition. Hence, although we did not find any positive relationship in line $\mathrm{C}$ between comb size at 16 weeks of age and viability in this study, where the cockerels were raised under 'conditions designed to maximize survival, we would expect to find a positive relationship between survival and comb size among line $\mathrm{C}$ males if they had been living in a natural environment (Zuk et al., 1990a).

Previous studies on a natural population of pheasants have reported a positive phenotypic correlation between spur length and viability (Göransson et al., 1990; Wittzell, 1991b; Grahn, 1993). Such a relationship was also found among the cockerels in the selection line (Table 7). Although there was a correlated response of reduced spur length because of selection for large combs in line S (Table 1), spur length per se has not been subject to direct selection in this study. It seems, therefore, as if the conditiondependent expression of spur length has not been distorted by the selection on comb size, although the two ornaments may be genetically correlated (Table 5). Spur length was also positively correlated with testes mass, both phenotypically (both lines; Tables 2 and 3) and genetically (line S; Table 5). 


\section{Male ornaments and female choice}

Several authors (Burley, 1981; Wittzell, 1991a; Zuk et al., 1992) have suggested that females select mates based on the assessment of several secondary male characters. If so, one may expect females to prefer males whose phenotypical expression of the traits lies above the population mean. The mate choice experiment in the present study distinguished a significant effect of the joint expression of comb size and spur length on female choice. As males from both line $S$ (with large combs and short spurs, Table 1) and line $C$ (with small combs and long spurs) were used in the mate choice trials, the experimental set-up consisted of male phenotypes with a significant negative correlation between $\mathrm{CS}_{29}$ and $\mathrm{SL}_{52}$. With geometric mean regression of comb size on spur length, or vice versa (Sokal \& Rohlf, 1995), males with a positive residual were preferred by the females in comparison with males whose residual was negative. The factors affecting the residual value of one ornament regressed against another are most likely manifested by nonadditive genes and by interaction with the environment. Considering the great phenotypic plasticity found in many secondary ornaments (Alatalo et al., 1988; Zuk et al., 1990b; Wittzell, 1991a; Johnson et al., 1993) and the ornaments' condition dependence (von Schantz et al., 1989; Zuk et al., 1990a; Møller, 1991b; Hill, 1991), the magnitude and sign of the residual value may be dependent on phenotypic condition. We do not know how condition is inherited and we do not know whether genes that affect condition also have nonadditive effects on the phenotypic expression of secondary sexual ornaments. We note, however, that recent studies in birds have revealed that the offspring of more ornamented males may be more viable (Norris, 1993; Petrie, 1994; von Schantz et al., 1994), which indicates that females may improve some components of offspring fitness by their preference for more ornamented males.

\section{Acknowledgements}

We thank G. Andersson for enthusiastic aid in indoors fieldwork. We also thank S. Bensch, T. Fagerström, K. Johansson and H. G. Smith for valuable comments on the manuscript. The study was supported by grants from Pharmacia to M.T. and M.W., by grants to T.v.S. from the Swedish Natural Science Research Council and Carl Trygger's Foundation for Scientific Research, by grants from the National Swedish Environmental Protection Agency to G.G. and by grants from the Swedish
Research Council for Agriculture and Forestry to M.G. and H.W.

\section{References}

ALATAlo, R. V., hÖGLUND, J. AND LUNDBERG, A. 1988. Patterns of variation in tail ornament size in birds. Biol. J. Linn. Soc., 34, 363-374.

ANDERSSON, M. 1982. Female choice selects for extreme tail length in a widowbird. Nature, 299, 818-820.

ANDERSSON, M. 1986. Evolution of condition-dependent sex ornaments and mating preferences: sexual selection based on viability differences. Evolution, 40, 804-816.

ANDERsson, s. 1991. Bowers on the savannah: display courts and mate choice in a lekking widowbird. Behav. Ecol., 2, 210-218.

ANDERsSON, s. 1992. Female preference for long tails in lekking Jackson's widowbirds: experimental evidence. Anim. Behav., 43, 379-388.

BRADBURY, J. W. AND DAVIES, N. B. 1987. Relative roles of intra- and intersexual selection. In: Bradbury, J. W. and Andersson, M. B. (eds) Sexual Selection: Testing the Alternatives, pp. 143-163. John Wiley, Chichester.

BRILlARD, J. P. AND DE REVIERS, M. 1985. Testis development and daily sperm output in guineas submitted to progressively increasing daily photoperiods at different ages. Poult. Sci., 64, 713-717.

BURLEY, N. 1981. Mate choice by multiple criteria in a monogamous species. Am. Nat., 117, 515-528.

BURROWs, w. H. AND TITUS, H. w. 1939. Some observations on the semen production of the male fowl. Poult. Sci., 18, 8-10.

ENDLER, J. A. 1980. Natural selection on color patterns in Poecilia reticulata. Evolution, 34, 76-91.

FALCONER, D. S. 1981. Introduction to Quantitative Genetics, 2nd edn. Longman, New York.

GRAFEN, A. 1990a. Sexual selection unhandicapped by the Fisher process. J. Theor. Biol., 144, 473-516.

GRAFEN, A. 1990b. Biological signals as handicaps. $J$. Theor. Biol., 144, 517-546.

GRAHN, M. 1993. Mortality in the pheasant Phasianus colchicus during the breeding season. Behav. Ecol. Sociobiol., 32, 95-101.

GÖRANSSON, G., VON SCHANTZ, T., FRÖBERG, I., HELGÉE, A. AND WITTZELL, H. 1990. Male characteristics, viability and harem size in the pheasant, Phasianus colchicus. Anim. Behav., 40, 89-104.

HAMILTON, w. D. AND zUK, M. 1982. Heritable true fitness and bright birds: a role for parasites? Science, 218, 384-387.

HARVEY, W. R. 1985. User's Guide for LSMLMW85. Ohio State University, Columbus, $\mathrm{OH}$.

HILL, G. E. 1991. Plumage coloration is a sexually selected indicator of male quality. Nature, 350, 337-339.

Hillgarth, N. 1990. Parasites and female choice in the ring-necked pheasant. Am. Zool., 30, 227-233.

HOFFMAN, A. A. AND PARSONS, P. A. 1989. Selection for increased desiccation resistance in Drosophila melano- 
gaster: additive genetic control and correlated responses for other stresses. Genetics, 122, 837-845.

HOSMER, D. W. Jr, AND LEMESHOW, s. 1989. Applied Logistic Regression. Wiley and Sons, New York.

HÖGLUND, J., ERIKSSON, M. AND LINDELL, L. E. 1990. Females of the lek-breeding great snipe, Gallinago media, prefer males with white tails. Anim. Behav., 40, 23-32.

JOHNSON, K., THORNHILL, R., LIGON, J. D. AND ZUK, M. 1993. The direction of mothers' and daughters' preferences and the heritability of male ornaments in red jungle fowl (Gallus gallus). Behav. Ecol., 4, 254-259.

KIRKPATRICK, M. AND RYAN, M. J. 1991. The evolution of mating preferences and the paradox of the lek. Nature, 350, 33-38.

KODRIC-BROWN, A. AND BROWN, J. H. 1984. Truth in advertising: the kinds of traits favoured by sexual selection. Am. Nat., 124, 309-323.

KRUIJT, J. P. 1964. Ontogeny of social behaviour in Burmese red jungle fowl (Gallus gallus spadiceus). Behav. Suppl., 12, 1-201.

LILIEDAHL, L.-E., KOLSTAD, N., SøRENSEN, P. AND MAIJALA, A. K. 1979. Scandinavian selection and crossbreeding experiment with laying hens. I. Background and general outline. Acta Agric. Scand., 29, 273-286.

MARTIN, P. A. AND DZIUK, P. J. 1977. Assessment of relative fertility of males (cockerels and boars) by competitive mating. J. Reprod. Fert., 49, 323-329.

MILINSKI, M. AND BAKKER, T. C. M. 1990. Female sticklebacks use male coloration in mate choice and hence avoid parasitized males. Nature, 344, 330-333.

MøLLER, A. P. 1988. Female choice selects for male sexual tail ornaments in the monogamous swallow. Nature, 332, 640-642.

MøLLER, A. P. 1989a. Viability costs of male tail ornaments in a swallow. Nature, 339, 132-135.

MøLLER, A. P. $1989 \mathrm{~b}$. Natural and sexual selection on a plumage signal of status and morphology in house sparrows, Passer domesticus. J. Evol. Biol., 2, 125-140.

MøLlER, A. P. 1991a. Sexual selection in the monogamous barn swallow (Hirundo rustica). I. Determinants of tail ornament size. Evolution, 45, 1823-1836.

MøLLER, A. P. 1991b. Viability is positively related to degree of ornamentation in male swallows. Proc. $R$. Soc. B, 243, 145-148.

NORRIS, K. 1990. Female choice and the evolution of the conspicuous plumage colouration of monogamous male great tits. Behav. Ecol. Sociobiol., 26, 129-138.

NORRIS, K. 1993. Heritable variation in a plumage indicator of viability in male great tits Parus major. Nature, 362, 537-539.

PARTRIDGE, L. AND FOWLER, K. 1993. Responses and correlated responses to artificial selection on thorax length in Drosophila melanogaster. Evolution, 47, 213-226.

PETRIE, M. 1994. Improved growth and survival of off- spring of peacocks with more elaborate trains. Nature, 371, 598-599.

QUAAS, R. L. 1976. Computing the diagonal elements and inverse of a large numerator relationship matrix. Biometrics, 32, 949-953.

ROSE, M. R. 1982. Antagonistic pleiotropy, dominance, and genetic variation. Heredity, 48, 63-78.

SOKAL, R. R. AND ROHLF, F. J. 1995. Biometry, 3rd edn. W. H. Freeman, New York.

STEINBERG, D. AND COLLA, P. 1991. LOGIT. A Supplementary Module for SYSTAT. SYSTAT, Evanston, IL.

TSUIJ, L. J. S., KOZLOVIC, D. R. AND SOKOLOWSKI, M. B. 1992. Territorial position in Sharp-tailed Grouse leks: the probability of fertilization. Condor, 94, 1030-1031.

TUFVESSON, M., VON SCHANTZ, T., JOHANSSON, K. AND WILHELMSON, M. 1993. Genetic parameters for sexual characters in white leghorn cockerels selected for large combs. 44th Annual Meeting of the European Association of Animal Production, 16-19 August 1993, Aarhus, Denmark. Fredriksberg, Aarhus.

TUTTLE, M. AND RYAN, M. J. 1981. Bat predation and the evolution of frog vocalizations in the neotropics. Science, 214, 677-678.

VON SCHANTZ, T., GÖRANSSON, G., ANDERSSON, G., FRÖBERG, I., GRAHN, M., HELGÉE, A. AND WITTZELL, H. 1989. Female choice selects for a viability-based male trait in pheasants. Nature, 337, 166-169.

VON SCHANTZ, T., GRAHN, M. AND GÖRANSSON, G. 1994. Intersexual selection and reproductive success in the pheasant Phasianus colchicus. Am. Nat., 144, 510-527.

WILKINSON, L. 1992. SYSTAT for Windows, version 5. SYSTAT, Evanston, IL.

witTZELl, H. 1991a. Natural and Sexual Selection in the Pheasant Phasianus colchicus. Ph.D. Thesis, University of Lund, Sweden.

WITTZELL, H. 1991b. Directional selection on morphology in the pheasant, Phasianus colchicus. Oikos, 61, $394-400$.

WRIGHT, s. 1922. Coefficients of inbreeding and relationship. Am. Nat., 56, 330-338.

ZAHAVI, A 1975. Mate selection - a selection for a handicap. J. Theor. Biol., 53, 205-214.

ZAHAVI, A. 1977. The cost of honesty: further remarks on the handicap principle. J. Theor. Biol., 67, 603-605.

ZUK, M., LIGON, J. D. AND THORNHILL, R. 1992. Effects of experimental manipulation of male secondary sex characters on female mate preferences in red jungle fowl. Anim. Behav., 44, 999-1006.

ZUK, M., THORNHILL, R., LIGON, J. D. AND JOHNSON, K. 1990a. Parasites and mate choice in red jungle fowl. Am. Zool., 30, 235-244.

ZUK, M., THORNHILL, R., LIGON, J. D., JOHNSON, K., AUSTAD, S., LIGON, S. H., THORNHILL, N. v. AND COSTIN, C. 1990 b. The role of male ornaments and courtship behaviour in female mate choice of red jungle fowl. Am. Nat., 136, 459-473. 